\title{
Six years of development in promoting identity formation of STEM education as a distinct field
}

Yeping Li

\begin{abstract}
With the completion of six publication cycle years (August 2014 to July 2020), the International Journal of STEM Education has achieved important milestones in promoting the identity of STEM education as a distinct field. In this editorial, I specifically share the journal's achievements since August 2019 and its emerging trends in leading research publications in STEM education, which reflect not only the journal's growth with on-going strong support from researchers and readers internationally, but also the gradual formation of a broad field identity of STEM education.
\end{abstract}

Keywords: Identity, Impact, Scholarship, SSCI journal, STEM education, STEM education research

\section{Introduction}

In the previous two editorials ( $\mathrm{Li}, 2018 \mathrm{a}, 2019)$, I summarized the journal's performance in publications over its first four and then first five publication cycle (PC) years since August 2014 respectively. The steady growth of quality publications has allowed the journal to not only serve as a gathering place for international researchers and readers to share scholarly work in science, technology, engineering and mathematics (STEM) education, but also take a leading role in promoting the scholarship development in STEM education research (Li, Wang, Xiao, \& Froyd, 2020a). Within 5 years of its establishment, the International Journal of STEM Education (IJ-STEM) was already being evaluated and selected for inclusion in both Web of Science's Social Sciences Citation Index (SSCI) by Clarivate Analytics and Elsevier's Scopus (Li, 2019).

In this editorial, I will share the journal's recent developments, especially in its sixth PC year since August 2019. In light of the journal's on-going development and performance, I will further discuss how STEM education has been moving forward to build its own identity

Correspondence: yepingli@tamu.edu

Texas A\&M University, College Station, TX 77843-4232, USA gradually. Thus, the following sections are organized in two main parts, the first about the journal's progress, and the second about the broad identity formation of STEM education as a distinct field. The editorial will conclude with acknowledgments to STEM education researchers and readers for the on-going strong support that helps make the journal a great success for all.

\section{Recent progress reflected in the journal's multiple performance measures}

Performance progress measured by indexing services

Because the IJ-STEM was evaluated for coverage in SSCI starting in 2019, the journal's citation performance in 2019 became available in the middle of 2020 . The very first impact factor (IF) of 1.850 places the journal at \#100 out of 263 journals currently covered by SSCI in the category of "Education \& Educational Research", and \#15 out of 41 journals in the sub-category of "Scientific Disciplines." The IF has positioned the journal in Quarter 2 among these 263 journals in 2019.

The journal received its first Scopus CiteScore (CS) of 2.40 from Elsevier in 2018 (Li, 2019). The CS of 2.40 ranked the journal in the 88th percentile (\#121) of 1038 education journals covered by Scopus at that time. 
Table 1 Top 10 most-cited articles published in 2019

\begin{tabular}{|c|c|c|}
\hline Title & Author & Country ${ }^{a}$ \\
\hline Teachers' perception of STEM integration and education: a systematic literature review & Margot \& Kettler, 2019 & USA \\
\hline Perceived supports and evidence-based teaching in college STEM & $\begin{array}{l}\text { Bathgate, Aragón, Cavanagh, } \\
\text { et al., } 2019\end{array}$ & USA \\
\hline $\begin{array}{l}\text { A descriptive study of race and gender differences in how instructional style and perceived professor care } \\
\text { influence decisions to major in STEM }\end{array}$ & $\begin{array}{l}\text { Rainey, Dancy, Mickelson, } \\
\text { et al., } 2019\end{array}$ & USA \\
\hline $\begin{array}{l}\text { Universal Design for Learning in postsecondary STEM education for students with disabilities: a systematic } \\
\text { literature review }\end{array}$ & $\begin{array}{l}\text { Schreffler, Vasquez III, Chini, } \\
\text { et al., } 2019\end{array}$ & USA \\
\hline Problematizing teaching and learning mathematics as "given" in STEM education & Li \& Schoenfeld, 2019 & USA \\
\hline $\begin{array}{l}\text { Supporting improvements to undergraduate STEM instruction: an emerging model for understanding } \\
\text { instructional change teams }\end{array}$ & $\begin{array}{l}\text { Olmstead, Beach, \& } \\
\text { Henderson, } 2019\end{array}$ & USA \\
\hline $\begin{array}{l}\text { Learning about research and readership development in STEM education: a systematic analysis of the } \\
\text { journal's publications from } 2014 \text { to } 2018\end{array}$ & Li, Froyd, \& Wang, 2019a & USA \\
\hline Exploring student understanding of the engineering design process using distractor analysis & $\begin{array}{l}\text { Wind, Alemdar, Lingle, et al., } \\
2019\end{array}$ & USA \\
\hline Evidence that communities of practice are associated with active learning in large STEM lectures & $\begin{array}{l}\text { Tomkin, Beilstein, Morphew, } \\
\text { et al., } 2019\end{array}$ & USA \\
\hline Sustaining pedagogical change via faculty learning community & $\begin{array}{l}\text { Tinnell, Ralston, Tretter, et al., } \\
2019\end{array}$ & USA \\
\hline
\end{tabular}

${ }^{a}$ Country refers to where the corresponding author's research organization or institution is located

Recently, Scopus changed its CS calculation formula. Instead of calculating citations on publications in the prior 3 years (see https://www.elsevier.com/editors-update/ story/journal-metrics/citescore-a-new-metric-to-helpyou-choose-the-right-journal), CS is now calculated based on citations of 4 years' publications (i.e., 20162019) received in these same 4 years. Thus, it is inevitable that the formula change would have advantages and disadvantages to different journals in various situations. For example, new journals, with a short history and generally fewer citations at the initial stage (this journal started in 2014), is disadvantaged compared to older, more established journals. In addition, we noticed that the change introduced some errors and inconsistencies in selecting and classifying publication items that brought negative impacts to the CS calculation for this journal ${ }^{1}$. Based on the CS calculation without making any error correction, the journal received a 2019 CS of 3.0. Although the value is higher than the 2018 CS of 2.40 , the journal's ranking decreased from the 88th percentile (\#121 out of 1038 education journals covered by Scopus) to the 83rd percentile (\#203 out of 2034 education journals currently covered).

In addition, the journal received the Source Normalized Impact per Paper (SNIP) of 2.058 and its first-ever SCImago Journal Rank (SJR) of 0.847 in 2020. With the calculation of weighted citations, SJR provides a

\footnotetext{
${ }^{1}$ We shared with Scopus about these errors. If these errors were corrected, the CS might be different for this journal. We certainly hope things will become better in reliability with the CS calculation in the future.
}

measurement of the journal's performance comparable across different fields. The SJR value of 0.847 (2019) places the journal in Quarter 1 in the category of Education covered by Scopus.

To illustrate journal article citation trends, we can take a closer look at some of the most-cited publications. For articles published in 2019, Table 1 shows the top 10 most-cited publications in descending order. Although specific topics covered by these most-cited articles do not seem to present particular foci, their titles suggest that the vast majority of these articles are about STEM rather than one of the component disciplines of STEM. The pattern suggests that the journal has attracted the kinds of articles it hopes to attract, a result consistent with what were reported in prior editorials $(\mathrm{Li}, 2018 \mathrm{a}$, 2019; Li, Wang, Xiao, \& Froyd, 2020a). At the same time, the result also suggests that the journal has become an important place for researchers who are looking to read and cite articles in STEM education research.

Moreover, all of these most-cited articles were contributed by scholars affiliated with a research organization or institution in the USA. The result illustrates active development and leadership in STEM education research in the USA, as reflected in this journal, a pattern consistent with data from previous years (Li, Froyd, \& Wang, 2019a; Li, Wang, Xiao, \& Froyd, 2020a).

Performance progress measured in terms of the number of publications and downloads

The IJ-STEM published a total of 55 articles (including research articles, reviews, commentaries, etc.) in its sixth 


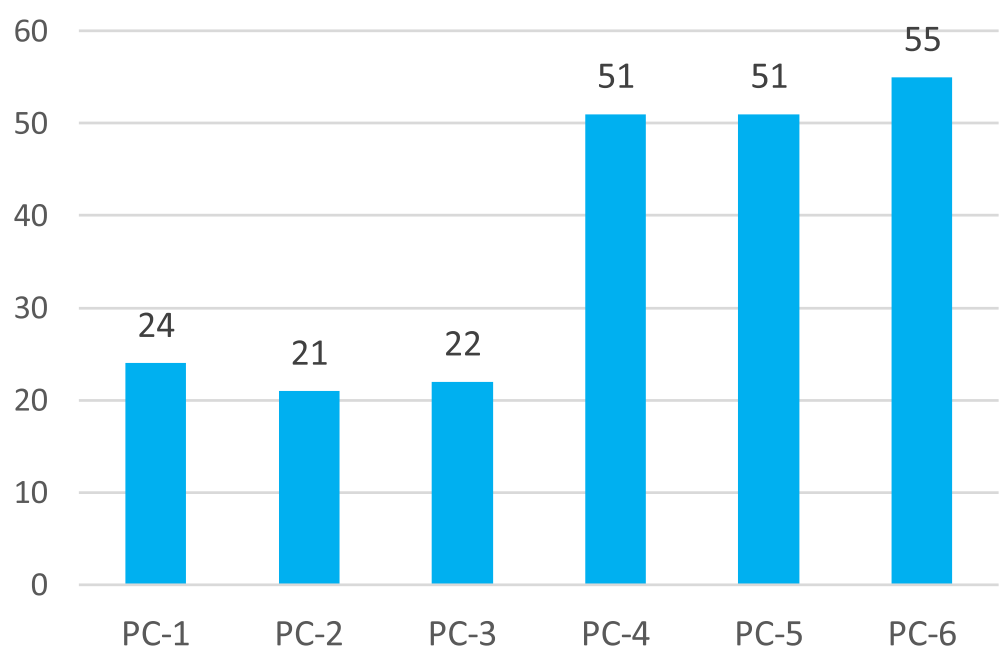

Fig. 1 Number of articles by publication cycle year

PC year (August 2019 to July 2020). Figure 1 shows the journal's growth in terms of the number of publications in each cycle year, from August 2014 to July 2020. Based on the last three PC years, it is clear that the journal has stabilized in terms of the number of published articles.

To get a better sense of the journal's progress, we should also look at aspects beyond the indexing services and the number of published articles. One important aspect is the number of article accesses and downloads from this journal. Over the years, the journal's publications have been increasingly accessed by researchers and readers worldwide. Figure 2 shows the total number of times journal publications were accessed by year. Overall, we can notice two important features:
(1) Over the 6 years from 2014 to 2019, there had been a phenomenal increase of accesses from 6669 to 373,846 .

(2) The trend of access increase has been overall consistent during the past 3 years: from $2016(54,883$ times) to 2017 (119,095 times), a 117\% increase or net 64,212 more accesses in 2017; from 2017 (119,095 times) to 2018 (217,873 times), an 83\% increase or net 98,778 more accesses in 2018; from 2018 (217,873 times) to 2019 (373,846 times), a 72\% increase or net 155,973 more accesses in 2019.

Apart from merely reflecting an increase in the number of articles available to be accessed, the number of

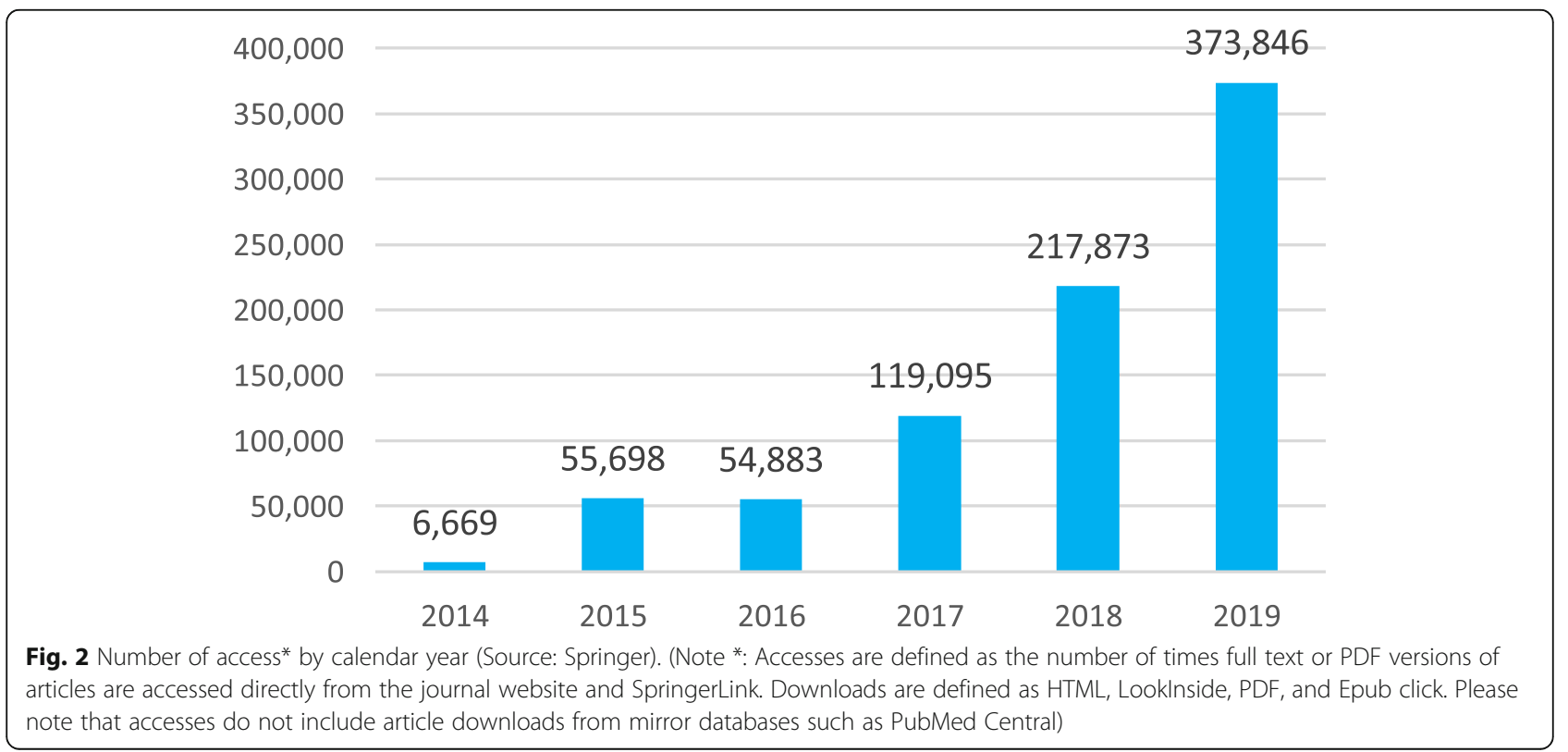


accesses each year and its increasing trend also provide clear indications that (1) high-quality articles are being published in this journal and (2) there is an increasing interest in STEM education research worldwide.

Taken together, these two figures provide a glimpse of the on-going mutually supportive development of scholarly activity and readership in STEM education internationally.

To examine further journal article accesses, we can take a closer look at some most-accessed articles. The top 10 most-accessed articles in each year from 2014 to 2018 were reported in a previous editorial (Li, Froyd, \& Wang, 2019a). Table 2 shows the top 10 most-accessed articles in 2019 in descending order. Similar to what we noticed before (Li, Froyd, \& Wang, 2019a), the top 10 list has little overlap with the top 10 lists of previous years, even though the publication dates are from 2015. Only the 2019 article by Margot and Kettler appeared in both the top 10 most-cited list and the top 10 mostaccessed list. Since the article is a literature review about teachers' perception of STEM integration, it may suggest a hot topic area in STEM education research. Moreover, consistent with what is noted about the top 10 mostcited list above, the vast majority of these 10 mostaccessed articles are about STEM rather than an individual STEM discipline. The result provides further confirmation about this journal's nature, as viewed by researchers and readers, and its success in what the journal aims to publish (Li, 2014).

Table 2 shows that the majority of the most-accessed publications in 2019 (7 out of 10) were contributed by scholars in the USA. There are three publications in the most-accessed article list contributed by scholars from the other three different countries (i.e., Australia,
Canada, and Cyprus). In contrast to the list of the top 10 most-cited articles (Table 1), this helps provide an excellent indication that STEM education research is also growing in other education systems. We will discuss more about this aspect in the next section.

\section{Performance progress measured in terms of readership and authorship development}

To examine the scope of the journal's impact, it is also important to learn about the journal's readership. Table 3 shows the top five countries or regions that accessed journal publications by year. It shows the international reach of the journal as well as shifts in access by country over the years. While the USA is almost always at the top of the list, it is interesting that most of the other countries or regions on the list are from Asia. Europe and Africa are relatively under-represented. The result is consistent with what we learned about the journal's readership in previous years (Li, Froyd, \& Wang, 2019a) and illustrates that the journal continues to be wellreceived and accessed beyond the USA.

The journal has functioned as a gathering place for international researchers and readers in STEM education ( $\mathrm{Li}, 2018 \mathrm{a})$. Although researchers from the USA contributed a vast majority of published articles (about 75\%) from 2014 to 2018 in this journal, the rest were contributed by researchers from a broad range of countries and regions (Li, Froyd, \& Wang, 2019a). In 2019, the international trend continued with contributions from scholars in countries or regions that did not happen before, such as Hong Kong, Indonesia, Japan, mainland China, and Taiwan. The increased authorship from Asia shows an encouraging sign consistent with the ongoing strong interest and readership in STEM education

Table 2 Top 10 most-accessed articles in 2019

\begin{tabular}{|c|c|c|}
\hline Title (publication year) & Author & Country $^{a}$ \\
\hline A conceptual framework for integrated STEM education (2016) & Kelley \& Knowles, 2016 & USA \\
\hline Teachers' perception of STEM integration and education: a systematic literature review (2019) & Margot \& Kettler, 2019 & USA \\
\hline Teachers' roles and identities in student-centered classrooms (2018) & Keiler, 2018 & USA \\
\hline STEM education K-12: perspectives on integration (2016) & English, 2016 & Australia \\
\hline $\begin{array}{l}\text { A study of the correlation between STEM career knowledge, mathematics self-efficacy, career interests, } \\
\text { and career activities on the likelihood of pursuing a STEM career among middle school students (2018) }\end{array}$ & $\begin{array}{l}\text { Blotnicky, Franz-Odendaal, } \\
\text { French, et al., } 2018\end{array}$ & Canada \\
\hline Making sense of "STEM education" in K-12 contexts (2018) & $\begin{array}{l}\text { Holmlund, Lesseig, \& Slavit, } \\
2018 .\end{array}$ & USA \\
\hline $\begin{array}{l}\text { Students' perceptions of STEM learning after participating in a summer informal learning experience } \\
(2018)\end{array}$ & $\begin{array}{l}\text { Roberts, Jackson, Mohr- } \\
\text { Schroeder, et al., } 2018\end{array}$ & USA \\
\hline $\begin{array}{l}\text { Multiple-true-false questions reveal more thoroughly the complexity of student thinking than multiple- } \\
\text { choice questions: a Bayesian item response model comparison (2019) }\end{array}$ & Brassil \& Couch, 2019 & USA \\
\hline Race and gender differences in how sense of belonging influences decisions to major in STEM (2018) & $\begin{array}{l}\text { Rainey, Dancy, Mickelson, et al., } \\
2018\end{array}$ & USA \\
\hline $\begin{array}{l}\text { The role of visual representations in scientific practices: from conceptual understanding and knowledge } \\
\text { generation to 'seeing' how science works (2015) }\end{array}$ & $\begin{array}{l}\text { Evagorou, Erduran, \& Mäntylä, } \\
2015\end{array}$ & Cyprus \\
\hline
\end{tabular}

${ }^{a}$ Country refers to where the corresponding author's research organization or institution is located 
Table 3 Top five countries or regions that accessed the journal's publications by year

\begin{tabular}{llllll}
\hline Rank & $\mathbf{2 0 1 9}$ & $\mathbf{2 0 1 8}$ & $\mathbf{2 0 1 7}$ & $\mathbf{2 0 1 6}$ & $\mathbf{2 0 1 5}$ \\
\hline 1 & USA & India & USA & USA & USA \\
2 & Philippines & USA & Philippines & Indonesia & Indonesia \\
3 & Indonesia & Brazil & Indonesia & Philippines & Turkey \\
4 & India & Philippines & India & India & UK \\
5 & Australia & Indonesia & Australia & Thailand & Hong Kong \\
\hline
\end{tabular}

Source: Google analytics

research in that region (see Table 3). It is a scholarship development trend that we hoped to see, as indicated in a previous report (Li, Froyd, \& Wang, 2019a).

\section{Promoting identity formation of STEM education}

Although STEM education, as explicated by the term, does not have a long history, it has experienced dramatic and rapid development as a movement in the USA and internationally (Li, 2018b; Li \& Anderson, 2020). Unlike a traditional discipline-based field like mathematics, STEM is not well defined and is thus open to different interpretations. Specifically, there is no single agreedupon disciplinarity about STEM. Still, the field is characterized by multiple developing perspectives about STEM education, such as discussions about knowledge-based STEM competencies (Tytler, 2020) and thinking development in and through STEM education ( $\mathrm{Li}$ et al., 2019b). All of these developments reflect STEM education research in its early stages.

Like the development trajectory of many other fields such as mathematics education, STEM education development as a distinct field will take long-term dedication and broad collaborations. There are some specific aspects that are commonly considered in identifying and tracing the identity formation of a field. For example, Kilpatrick (2008) traced the development of mathematics education as a field of study and practice distinct from mathematics. He highlighted several aspects, including the establishment of professional organizations and non-profit organizations by and for those who identified themselves as mathematics educators, mathematics education being institutionalized with diversity across countries, and in ways related to mathematics. In addition, there are other aspects being commonly referred to (Li \& Lewis, 2019): (1) specific issues in mathematics education such as student learning, curriculum, testing, and teacher education, beyond teaching itself, began to be identified and studied; (2) professional conferences being organized for those interested in relevant issues in mathematics education; and (3) the establishment of specific journals including Educational Studies in Mathematics, the Journal for Research in Mathematics Education, and ZDM.
In reference to the development trajectory of mathematics education as a field, it becomes clearer that STEM education is also well into its development trajectory for establishing itself as a distinct field. By focusing on the following aspects, we can better understand the ongoing development of identity formation of STEM education.

1. Identity formation in terms of establishing professional organizations, institutionalization (such as programs and centers), and professional conferences: we can easily identify numerous developments over the past decade in this aspect (e.g., Li, 2014).

2. Identity formation in terms of the development and implementation of educational policy and funding support for programs and research specifically related to STEM education: it is clear that STEM education has been a national priority in the USA and several other education systems (e.g., Li, Wang, Xiao, Froyd, \& Nite, 2020b).

3. Identity formation in terms of establishing professional journals: we have learned from literature reviews about tremendous developments in this aspect (e.g., Li, Froyd, \& Wang, 2019a; Li, Wang, Xiao, \& Froyd, 2020a).

4. Identity formation in terms of scholarship development with specifically identified issues and sets of questions: it will take much longer time, effort, and extensive collaborations to work on this aspect.

To review the state of STEM education development, further evidence and extensive discussion would certainly be needed beyond the scope of this editorial. However, specifically related to the third aspect listed above, a recent review of publications in 36 journals revealed that STEM education research is increasing in importance internationally, and the identity of STEM education journals is becoming clearer over time (Li, Wang, Xiao, \& Froyd, 2020a). The review also showed that the IJSTEM had outstanding performance in attracting and publishing STEM education articles since the journal's inception in 2014. As the journal was accepted as the first STEM education journal for inclusion in SSCI starting in 2019 (Li, 2019), the recognition marked an important milestone for STEM education journals as a distinct platform to promote STEM education's identity formation.

It is no doubt that the journal's success relies on tremendous on-going support from all contributors, reviewers, readers, editorial board members, and staff members at SpringerOpen. I want to take this opportunity to thank everyone for all the support and 
contribution to the journal over the past 6 years. As a leading journal in STEM education research, the recognition is both an honor and an obligation to help further the development of STEM education scholarship internationally. Taken as the theme for this editorial, it is my hope that the journal will continue to serve as a gathering place for researchers and readers worldwide to share research and promote the identity formation of STEM education as a distinct field.

\section{Note}

The journal used to publish four types of articles: research articles, reviews, short reports, and commentaries. It happened often that the category of short reports can easily cause misunderstanding about the nature of manuscripts that can be submitted for publication considerations. Thus, we decided to eliminate the category of short reports. Now the journal publishes three types of articles (i.e., research articles, reviews, and commentaries). Contributors can still submit research article manuscripts short in length, but the same quality expectation would apply to all research articles.

\section{Acknowledgements}

The author would like to thank Hendrikje Tuerlings, Marius Jung, and other staff at Springer Nature for providing relevant data and valuable feedback on an earlier version of this editorial. Thanks also go to Christian D. Schunn, Kaye Stacey, Jon R. Star, and Jamaal Young for their careful reviews and valuable suggestions to improve this editorial.

\section{Author's contributions}

This work was conducted by a sole author. The author read and approved the final manuscript.

\section{Funding}

Not applicable.

\section{Availability of data and materials}

The data and materials used and analyzed for the editorial were these articles published in this journal or were provided by Springer. Journal article information is publicly available at the journal's website (https:// stemeducationjournal.springeropen.com).

\section{Competing interests}

The author declares that he has no competing interests.

Received: 14 November 2020 Accepted: 16 November 2020 Published online: 03 December 2020

\section{References}

Bathgate, M. E., Aragón, O. R., Cavanagh, A. J., et al. (2019). Perceived supports and evidence-based teaching in college STEM. International Journal of STEM Education, 6, 11. https://doi.org/10.1186/s40594-019-0166-3.

Blotnicky, K. A., Franz-Odendaal, T., French, F., et al. (2018). A study of the correlation between STEM career knowledge, mathematics self-efficacy, career interests, and career activities on the likelihood of pursuing a STEM career among middle school students. International Journal of STEM Education, 5, 22. https://doi.org/10.1186/s40594-018-0118-3.

Brassil, C. E., \& Couch, B. A. (2019). Multiple-true-false questions reveal more thoroughly the complexity of student thinking than multiple-choice questions: a Bayesian item response model comparison. International Journal of STEM Education, 6, 16. https://doi.org/10.1186/s40594-019-0169-0.
English, L. D. (2016). STEM education K-12: Perspectives on integration. International Journal of STEM Education, 3, 3. https://doi.org/10.1186/s40594016-0036-1.

Evagorou, M., Erduran, S., \& Mäntylä, T. (2015). The role of visual representations in scientific practices: from conceptual understanding and knowledge generation to 'seeing' how science works. International Journal of STEM Education, 2, 11. https://doi.org/10.1186/s40594-015-0024-x.

Holmlund, T. D., Lesseig, K., \& Slavit, D. (2018). Making sense of "STEM education" in K-12 contexts. International Journal of STEM Education, 5, 32. https://doi. org/10.1186/s40594-018-0127-2.

Keiler, L. S. (2018). Teachers' roles and identities in student-centered classrooms. International Journal of STEM Education, 5, 34. https://doi.org/10.1186/s40594018-0131-6.

Kelley, T. R., \& Knowles, J. G. (2016). A conceptual framework for integrated STEM education. International Journal of STEM Education, 3, 11. https://doi.org/10. 1186/s40594-016-0046-z.

Kilpatrick, J. (2008). The development of mathematics education as an academic field. In M. Menghini, F. Furinghetti, L. Giacardi, \& F. Arzarello (Eds.), The first century of the International Commission on Mathematical Instruction (19082008). Reflecting and shaping the world of mathematics education, (pp. 25-39). Rome: Istituto della Enciclopedia Italiana.

$L i, Y$. (2014). International journal of STEM education - A platform to promote STEM education and research worldwide. International Journal of STEM Education, 1, 1. https://doi.org/10.1186/2196-7822-1-1.

Li, Y. (2018a). Four years of development as a gathering place for international researchers and readers in STEM education. International Journal of STEM Education, 5, 54. https://doi.org/10.1186/s40594-018-0153-0.

Li, Y. (2018b). Journal for STEM Education Research - Promoting the development of interdisciplinary research in STEM education. Journal for STEM Education Research, 1(1-2), 1-6. https://doi.org/10.1007/s41979-0180009-z.

$\mathrm{Li}, \mathrm{Y}$. (2019). Five years of development in pursuing excellence in quality and global impact to become the first journal in STEM education covered in SSCl. International Journal of STEM Education, 6, 42. https://doi.org/10.1186/s40594019-0198-8.

Li, Y., \& Anderson, J. (2020). STEM integration: diverse approaches to meet diverse needs. In J. Anderson, \& Y. Li (Eds.), Integrated approaches to STEM education: An international perspective, (pp. 15-20). Cham: Springer.

Li, Y., Froyd, J. E., \& Wang, K. (2019a). Learning about research and readership development in STEM education: A systematic analysis of the journal's publications from 2014 to 2018. International Journal of STEM Education, 6, 19. https://doi.org/10.1186/s40594-019-0176-1.

Li, Y., \& Lewis, W. J. (2019). Recognizing and promoting interdisciplinary collaboration, leadership, and impact: award for interdisciplinary excellence in mathematics education (IEME award). International Journal of STEM Education, 6, 9. https://doi.org/10.1186/s40594-019-0162-7.

Li, Y. \& Schoenfeld, A. H. (2019). Problematizing teaching and learning mathematics as 'given' in STEM education. International Journal of STEM Education, 6, 44. https://doi.org/10.1186/s40594-019-0197-9.

Li, Y., Schoenfeld, A. H., disessa, A. A., Grasser, A. C., Benson, L. C., English, L. D., \& Duschl, R. A. (2019b). On thinking and STEM education. Journal for STEM Education Research, 2(1), 1-13. https://doi.org/10.1007/s41979-019-00014-X.

Li, Y., Wang, K., Xiao, Y., \& Froyd, J. E. (2020a). Research and trends in STEM education: A systematic review of journal publications. International Journal of STEM Education, 7, 11. https://doi.org/10.1186/s40594-020-00207-6.

Li, Y., Wang, K., Xiao, Y., Froyd, J. E., \& Nite, S. B. (2020b). Research and trends in STEM education: a systematic analysis of publicly funded projects. International Journal of STEM Education, 7, 17. https://doi.org/10.1186/s40594020-00213-8.

Margot, K. C., \& Kettler, T. (2019). Teachers' perception of STEM integration and education: A systematic literature review. International Journal of STEM Education, 6, 2. https://doi.org/10.1186/s40594-018-0151-2.

Olmstead, A., Beach, A., \& Henderson, C. (2019). Supporting improvements to undergraduate STEM instruction: an emerging model for understanding instructional change teams. International Journal of STEM Education, 6, 20. https://doi.org/10.1186/s40594-019-0173-4.

Rainey, K., Dancy, M., Mickelson, R., et al. (2018). Race and gender differences in how sense of belonging influences decisions to major in STEM. International Journal of STEM Education, 5, 10. https://doi.org/10.1186/s40594-018-0115-6.

Rainey, K., Dancy, M., Mickelson, R., et al. (2019). A descriptive study of race and gender differences in how instructional style and perceived professor care 
influence decisions to major in STEM. International Journal of STEM Education, 6, 6. https://doi.org/10.1186/s40594-019-0159-2.

Roberts, T., Jackson, C., Mohr-Schroeder, M. J., et al. (2018). Students' perceptions of STEM learning after participating in a summer informal learning experience. International Journal of STEM Education, 5, 35. https://doi.org/10. 1186/s40594-018-0133-4.

Schreffler, J., Vasquez III, E., Chini, J., et al. (2019). Universal Design for Learning in postsecondary STEM education for students with disabilities: a systematic literature review. International Journal of STEM Education, 6, 8. https://doi.org/ 10.1186/s40594-019-0161-8.

Tinnell, T. L., Ralston, P. A. S., Tretter, T. R., et al. (2019). Sustaining pedagogical change via faculty learning community. International Journal of STEM Education, 6, 26. https://doi.org/10.1186/s40594-019-0180-5.

Tomkin, J., Beilstein, S., Morphew, J., et al. (2019). Evidence that communities of practice are associated with active learning in large STEM lectures. International Journal of STEM Education, 6, 1. https://doi.org/10.1186/s40594018-0154-z.

Tytler, R. (2020). STEM education for the $21^{\text {st }}$ century. In J. Anderson, \& Y. Li (Eds.), Integrated approaches to STEM education: An international perspective, (pp. 21-43). Cham: Springer.

Wind, S. A., Alemdar, M., Lingle, J. A., et al. (2019). Exploring student understanding of the engineering design process using distractor analysis. International Journal of STEM Education, 6, 4. https://doi.org/10.1186/s40594018-0156- $\mathrm{x}$

\section{Publisher's Note}

Springer Nature remains neutral with regard to jurisdictional claims in published maps and institutional affiliations.

\section{Submit your manuscript to a SpringerOpen ${ }^{\circ}$ journal and benefit from:}

- Convenient online submission

- Rigorous peer review

- Open access: articles freely available online

High visibility within the field

- Retaining the copyright to your article

Submit your next manuscript at $\boldsymbol{\nabla}$ springeropen.com 